\title{
ENTREVISTA COM O PROFESSOR PAULO PINHEIRO MACHADO
}

\author{
Luiz Felipe Florentino*
}

\begin{abstract}
RESUMO
Nesta entrevista o Professor Paulo Pinheiro Machado responde questões relacionadas à docência, história do campesinato, Contestado, ditadura militar brasileira e alguns aspectos da política brasileira atual.
\end{abstract}

Palvras-chave: Campesinato; Contestado; História Social

O professor e historiador Paulo Pinheiro Machado é professor associado do Departamento de História da Universidade Federal de Santa Catarina, ministrando aulas no Curso de Graduação e no Programa de Pós-Graduação em História, atualmente ocupa o cargo de Diretor do Centro de Filosofia e Ciências Humanas da mesma universidade. Graduado em história pela Universidade Federal do Rio Grande do Sul, mestre e doutor em história pela Universidade Estadual de Campinas, além de possuir pós-doutorado pela Universidade Federal Fluminense e Universitat Autonoma de Barcelona. Possui larga experiência na área de história social do campesinato, sendo um dos principais pesquisadores sobre $\mathrm{o}$ Contestado. É autor de uma série de artigos e dos livros A Política de Colonização do Império e Lideranças do Contestado. E na manhã do dia 25 de setembro de 2015 teve a gentileza de nos conceder a seguinte entrevista:

\footnotetext{
* Universidade Federal de Santa Catarina. E-mail contato: 1.f.florentino@ outlook.com.
} 

opção?

1 - Professor, lecionar história sempre foi sua primeira

Paulo Pinheiro Machado: Eu sempre gostei de história. Também não pensava que lecionar história seria a minha praia, eu não sabia disso. Foi mais com o tempo que fui aprendendo e gostando. Eu gosto de dar aula. É uma das coisas que acho mais importante na nossa profissão, tanto para graduação quanto para pós-graduação, até para públicos maiores. Eu estou acostumado a viajar pelo interior por conta da minha atividade de pesquisa e me pedem para falar sobre determinados assuntos, geralmente sobre o Contestado, então eu acho que isso está geneticamente dentro da nossa profissão, tanto a pesquisa quanto o ensino fazem parte da formação do historiador e não há como separar isso. São muito importantes.

2 - O senhor graduou-se na Universidade Federal do Rio Grande do Sul entre as décadas de setenta e oitenta, durante o governo de João Baptista Figueiredo e em plena ditadura militar. Que local o curso de história ocupava nesse contexto?

Paulo Pinheiro Machado: A história era um curso marginal, como todas as ciências humanas naquela época e continua marginal [risos]. Mas naquela época ela era vista com mais desconfiança ainda por ser uma área de subversivos, vamos dizer assim. Então a gente tinha, eu me lembro, na graduação alguns alunos e professores que eram delatores do regime militar, vivíamos num clima ainda, mesmo em 1979 com a anistia, com o início da chamada abertura, que era um processo ainda sob o controle dos militares, mas mesmo assim havia, em cada turma um sujeito que fingia ser estudante, que deixava a barba crescer, andava com chinelos. A gente sabia pelo próprio jargão, pelo próprio linguajar que tinha o vocabulário dos policiais, que falavam em "elemento" [risos], coisas assim... Então a história, fazer história naquela época tinha certo desafio político, assim de que quem optava por fazer o curso de história optava por questionar a ordem vigente. Isso era um sentimento que a minha geração teve naquela época, acho que isso era um clima, não só na minha universidade, notávamos nos encontros da ANPUH e nos encontros das entidades dos estudantes de história que isso era um clima 
nacional e até latino-americano, por causa das ditaduras militares nos países vizinhos também.

3 - Quais as principais dificuldades que os pesquisadores enfrentam ao abordar a questão camponesa aqui no Brasil? Haveria alguma relação com o acesso às fontes?

Paulo Pinheiro Machado: Eu acho que o acesso às fontes é um problema, é um problema até hoje, mas é o menor de todos. O problema maior é de concepção e de foco no que realmente representa o campesinato. Por quê? Por que o estudo do campesinato ele tem toda uma longa trajetória pelas ciências humanas no Brasil. Existiu uma visão muito forte por parte dos primeiros clássicos da historiografia, marcou muito a obra do Nelson Werneck Sodré a noção de que o campesinato brasileiro tinha uma luta legítima pela reforma agrária, isso em várias obras dele aparece porque fazia parte de uma luta antifeudal, então a emancipação do latifúndio, a reforma agrária como uma tarefa democrática burguesa para se consolidar o capitalismo no Brasil. O Caio Prado Jr. não concordava com isso, mas a visão do Caio Prado Jr. não era predominante nem na esquerda e também, posso dizer, nem nas ciências humanas, ele inclusive foi muito mais lido depois de morto. No caso tanto da história quanto da sociologia rural, da antropologia, todas essas áreas por volta dos anos 1970 e 1980, deixaram até de usar o termo "campesinato" entendendo que a industrialização da agricultura, o processo de desenvolvimento do capitalismo que aconteceu naqueles anos da ditadura militar e tudo mais, que tinham de certa forma, eu estou exagerando os termos, mas claramente isso aparece em alguns autores, eles tinham acabado com a questão agrária. A questão agrária não era mais uma questão. Porque o Brasil já era um país capitalista, mesmo que dependente, era um país capitalista. Então aquelas questões de restos feudais e outros essas visões já estariam superadas. Isso no campo teórico, só que no campo político e prático o processo de redemocratização no Brasil contou com um campo decisivo. Uma coisa foi à luta urbana dos estudantes, dos operários, das greves e tudo mais, outra coisa foi à luta no campo, que foi a retomada pela terra e pela reforma agrária que aconteceu a partir de 1977 lá em Sobradinho na Bahia, em 1978 no Bico de Papagaio na Amazônia e também na Encruzilhada 
Natalino no Rio Grande do Sul, logo depois em 1980 aqui a Fazenda Burro Branco em Santa Catarina, ocupações que foram organizadas por trabalhadores sem terra ainda sem nenhuma organização nacional, ainda não era o MST que só vai se formar em 1984, a Pastoral da Terra vai chegar depois dessas primeiras ocupações. Então eles vão construindo uma retomada pela luta da reforma agrária e com isso vão recriando politicamente o conceito de camponês. Até que no final dos anos 1980 e início dos anos 1990, as próprias ciências humanas vão redesenhar o conceito de campesinato, um campesinato existente dentro do capitalismo, um campesinato que mesmo dentro do capitalismo não vai ser diluído como entendiam ou como esperavam os clássicos, que a tendência numa sociedade capitalista seria só a proletarização geral, o assalariamento geral, no entanto mesmo numa sociedade capitalista desenvolvida como, por exemplo, na Europa Ocidental, na França, na Alemanha, na Espanha, Itália. Eles têm um campesinato que pode ter políticas de subsídio do Estado, pode ter uma série de outras situações, mas ele existe socialmente como uma força ainda viva nessas sociedades e no caso do Brasil, então apesar desse campesinato no capitalismo perder muito da sua autonomia original, apesar de estar submetido a um processo de produção que não é aquele tradicional do campesinato, muitas vezes ele está subordinado a uma integração a agroindústria ou uma subordinação a várias normas do mercado, afinal de contas ele continua vivendo numa sociedade no entorno capitalista, esse campesinato ele existe ele se reproduz apesar de todas as dificuldades. Estão aí as regiões coloniais que ainda existem, os assentamentos da reforma agrária que vivem em muitas regiões do interior apesar da política agrícola do Estado brasileiro continuar privilegiando o agronegócio e com isso continuar promovendo o êxodo rural. Então este é um problema é um conflito que existe no campo, mas a existência histórica do campesinato nos dias de hoje é evidente, então o campesinato que era muito mais um termo político usado pelos movimentos sociais ele foi ressuscitado como um conceito das ciências humanas nas últimas duas décadas, onde este conceito estava caindo em desuso, ele voltou a ser retomado, então as ciências acabaram aprendendo com a vida e com os movimentos sociais. A ideia de que a luta pela terra seria algo superado e que a partir de uma determinada época os trabalhadores do campo só se interessariam por carteira assinada, melhores condições 
de trabalho, INPS, aposentadoria, tanto quanto os trabalhadores da cidade, essa é a noção que se tinha de desenvolvimento, a industrialização do campo. Sim, em vários aspectos os trabalhadores do campo vão lutar por previdência e por melhores condições de trabalho, mas a condição camponesa de acesso a terra e do trabalho familiar da terra que caracteriza o campesinato, essa ainda existe e se reproduz nos dias de hoje, mesmo com dificuldades.

4 - A história do Brasil dita oficial, por vezes parece limitar a figura do camponês à Europa, como se durante todo o período colonial e monárquico a força de trabalho, tanto rural como urbano fosse exclusivamente escrava e o trabalho livre tivesse origem apenas com a República. O senhor concorda que existiu essa negligência quanto à abordagem da questão camponesa no Brasil?

Paulo Pinheiro Machado: Sim. Mas ela existe cada vez menos porque é crescente o número de estudos que tem, vamos dizer assim, desmanchado esse estereótipo de que no período colonial a sociedade brasileira era só formada por senhores e escravos. Hoje há toda uma nova historiografia, há uma nova sociologia e as outras áreas das ciências humanas que têm reconhecido a existência de roceiros, tanto mestiços, quilombolas, outros grupos sociais que viviam a condição camponesa desde os primeiros séculos da colonização e esse grupo de libertos e de homens e mulheres livres pobres, é uma população que vai crescendo no Brasil ao longo dos séculos e que não era submetida à grande propriedade, mas que vive em condições precárias porque não tem a propriedade formal da terra, porque vive numa situação de posse dos seus territórios. Esse é o grande campesinato brasileiro, tem um estudo levantado ainda pelo professor Ciro Flamarion Cardoso, publicado em 1979, chamado Agricultura, escravidão e capitalismo, ele já apontava isso, mesmo em grandes latifúndios açucareiros, cafeeiros, com muito emprego de mão de obra escrava, nesses locais existiam sempre roças dos próprios escravos e das famílias dos escravos, é o que ele chama de brecha camponesa dentro da escravidão. Ao final da escravidão, em várias regiões do norte e do nordeste do Brasil e mesmo do sudeste, vários dos ex-escravos continuaram morando nestas propriedades como parceiros, meeiros, moradores, foreiros em diferentes condições 
de pagamento de renda e aluguéis aos proprietários fundiários, mas nunca tendo uma condição de autonomia relativa e de acesso direto a terra para começar suas roças e pequenas criações. $\mathrm{O}$ campesinato na vida brasileira em geral, não só dentro como fora da escravidão, foi muito importante. A condição de livre no Brasil sempre foi muito precária, mesmo no tempo da escravidão como depois da escravidão, porque os homens pobres sempre estiveram também sujeitos a serem tangidos pelo Estado com o trabalho compulsório, uma das formas disso era o recrutamento militar, por exemplo. No recrutamento militar, pelo menos até o início do século $\mathrm{XX}$ o sujeito podia ser compulsoriamente recrutado, como dizia na época "a laço" e o recrutamento militar significava 14 ou 15 anos da sua vida como serviço obrigatório e no serviço obrigatório nas forças armadas frequentemente estava presente os castigos corporais, então para a condição do homem livre o recrutamento militar era quase um cativeiro, ou pelo menos um cativeiro temporário e não pouco temporário porque muitas vezes o próprio exército segurava os recrutas além do período dito oficial do recrutamento porque não se conseguia preencher as vagas com novos recrutas. Só para termos uma ideia: a linha de transmissão de telégrafos entre Cuiabá e Porto Velho que foi construída ali na década de 1910 pelo Rondon, ele utilizou mais de 300 soldados para derrubar 100 metros de mata fechada amazônica no sentido de Cuiabá e no sentido de Porto Velho, usando para isso soldados recrutados. $\mathrm{O}$ recrutamento forçado, portanto, serviu para construção de ferrovias, linhas telegráficas, fortes, colônias militares, abertura de estradas e construções de pontes. Quando não era possível empregar o trabalho escravo empregavam o trabalho compulsório desses trabalhadores. Aldeamentos indígenas também, frequentemente eram sujeitos à prestação de serviços para as províncias, para as municipalidades, para as ordens religiosas. Então mesmo os indígenas considerados pelos portugueses e depois pelos brasileiros como "mansos", "aldeados" elas estavam sujeitos a um regime de prestação de trabalho tal qual existia no mundo hispânico, como a Mita, o Mingado, a Encomienda, aquelas outras formas históricas de submissão do trabalho indígena. Isso também vigorava no Brasil, então hoje a historiografia do trabalho não faz mais barreiras muito grandes entre o trabalho escravos e o trabalho livre. Mesmo durante a 
escravidão como depois dela, porque formas compulsórias de trabalho continuam sendo identificadas mesmo hoje, não só no Brasil como no mundo todo e mesmo aquele marco que a historiografia tinha do 13 de Maio e depois mais tarde, depois do 13 de Maio uma historiografia do trabalho ligada ao estudo do operário, mas um operário imigrante, branco. Essa barreira já não existe mais na historiografia, tanto no meio rural como no meio urbano, identificou-se que há uma série de tradições, práticas de resistência dos trabalhadores mesmo durante a escravidão e que continuam depois dela. Então se pode dizer que este é um assunto bastante desenvolvido pela historiografia, principalmente nos últimos dez anos.

5 - Observei que em seus estudos são recorrentes a utilização de obras de Edward Palmer Thompson. Gostaria que o senhor pudesse avaliar a contribuição de Thompson para fundamentar uma história social do campesinato no Brasil.

Paulo Pinheiro Machado: O Thompson foi um historiador muito importante porque ele vem de um marxismo fortemente influenciado por uma tradição britânica de intelectuais engajados com a luta social e engajados também com uma postura e uma formulação de observação e de devido respeito à evidência empírica que também é um processo muito importante. Thompson nunca foi um empirista no sentido de alguém que negasse a importância do debate teórico e da formulação teórico-metodológico para o estudo da realidade, mas o que ele mais fez durante sua vida foi combater as visões esquemáticas e estruturalistas que matavam o sujeito, que só viam estruturas, forças, modos de produção e formulações teóricas quase que ocas e estéreis que não entendem a vida, o dinamismo e a luta de classe que são empreendidas pelos sujeitos no mundo real. Então nisso o Thompson trouxe uma contribuição fundamental e embora ele fosse um autor que nunca tenha estudado o Brasil, nunca tenha estudado a escravidão, ele estudou o campesinato, mas só o campesinato inglês que é sui generis e muito próprio e que foi erradicado pelos enclosures lands, as obras basilares dele como a Formação da classe operária inglesa e depois todos os outros artigos que foram reunidos naquele Tradição, revolta e consciência de classe e aquele artigo clássico dele sobre a economia moral da multidão, eles 
dão a nós uma percepção muito importante para quem estuda o campesinato, que é o seguinte: Thompson contextualiza a linguagem dos sujeitos sociais, então quando ele vê que, por exemplo, a plebe inglesa fazia movimentos e coloca esses movimentos em defesa do rei e da Igreja, o que parece um movimento ultraconservador, na prática o que estes sujeitos estão fazendo? Eles estão atacando molineiros, eles estão atacando especuladores de trigo, estão atacando comerciantes e atravessadores e utilizam um discurso do Antigo Regime, um discurso que era do paternalismo, o teatro do paternalismo para recuperar até antigas leis do pão, antigas leis dos Tudor que protegiam a população pobre para a luta pela sobrevivência, para defesa e para fixar os preços nos níveis históricos do trigo e do pão que eram fundamentais para vida e subsistência daquela população. Então quando ele consegue perceber que a linguagem só pode ser entendida junto com a ação, a ação é também linguagem: essa é a principal contribuição de Thompson do meu ponto de vista, não só para o campesinato como no estudo de qualquer movimento social onde nós precisamos entender a pauta daquele movimento num determinado contexto e o significado que os sujeitos dão a sua linguagem. Se não fosse o Thompson como nós entenderíamos o fato dos camponeses no Contestado fazerem uma defesa da monarquia? Eles queriam a volta ao passado? $\mathrm{O}$ atraso? Eles eram contra o progresso? E a Revolta da Vacina no Rio de Janeiro, eles eram contra a ciência? Não, nada disso. É que eles sentiram, eles experimentaram a ciência e o progresso como forma de expropriação da sua condição. Então o contexto teóricometodológico oferecido pela obra de Thompson nos dá instrumentos para entender a linguagem dos movimentos sociais e isso é importante, decisivo para os estudos de vários processos, então a cultura na visão de Thompson não é algo abstrato que está além das pessoas ou que é exercido só pela classe dominante. A cultura é aquilo que as pessoas fazem, não só o que elas pensam, é o que elas pensam e fazem. Isso é a cultura. Então, portanto o Thompson ele foi o inaugurador de uma história social da cultura na medida em que consegue entender as expectativas, os projetos, a lutas sociais e a linguagem dos de "baixo", isso é fundamental e entender os de "baixo" não quer dizer que não estude os de cima, porque os de "baixo" e os de "cima" vivem na mesma sociedade. O Thompson não gostava dessa 
denominação "história vista de baixo", isso foi dado por um resenhista de um periódico inglês, a "história vista de baixo" ele dizia assim, "É, mas quem estuda a história dos de baixo, a partir da perspectiva dos de 'baixo' precisa também entender o contexto maior e a política dos de cima". O Estado, as suas disputas políticas, os seus problemas e tal, porque mesmo a plebe teve que se focar em algumas expectativas e na divisão da gentry e de outros segmentos da sociedade inglesa para fazer a sua própria política e o que o Thompson vai dizer é justamente isso, o operariado inglês não nasce com a máquina, ele não é criado pela máquina, o operariado inglês ele é o resultado de séculos de formação política e social da antiga plebe inglesa, vai ganhar experiência, vai ganhar uma concepção de mundo, de vida, de conceitos, até de cidadania. Como dizia, um inglês nascido livre fazia parte do imaginário da plebe e também da classe trabalhadora inglesa. Então tem uma continuidade, ninguém vai conseguir entender o movimento ludista ou até o movimento cartista da Inglaterra se não entender a tradição que vem dos séculos passados de uma plebe turbulenta e rebelde que tem uma cultura ambígua, frequentemente ligada até a um discurso do Antigo Regime, mas que precisa ser entendida no seu contexto.

\section{6 - E de onde surgiu a inspiração para pesquisar o} Contestado?

Paulo Pinheiro Machado: Praticamente no final da minha graduação, entre 1981 e 1982 que eu li mesmo sobre o Contestado. Eu praticamente desconhecia o movimento e eu li o livro do professor Mauricio Vinhas de Queiroz, Messianismo e Conflito Social, que é uma grande obra, eu acho que até hoje é a maior pesquisa sobre o Contestado. Ele teve um trabalho muito grande, o livro é um acervo de fontes extraordinário e eu fiquei vidrado naquilo. Como é que um movimento desse tamanho não é do conhecimento das pessoas comuns? Como é que isso passa despercebido nas escolas? Naquela época muito mais do que hoje. Hoje ainda entra um pouquinho, cada vez mais, dependendo do lugar e dos professores, mas naquela época era simplesmente um assunto silenciado, não se falava disso. Então a partir daquele momento eu me interessei, mas eu vivia no Rio Grande do Sul e até a minha dissertação de mestrado foi sobre a colonização 
imperial no Rio Grande do Sul. Depois que eu me mudei para cá é que passei realmente a me focar nisso e a ler vários outros autores, até que eu fiz o projeto de doutorado e entrei no doutorado em 1997 na Unicamp e fiz a minha tese sobre o Contestado, defendida em 2001, então ali foi o período que eu realmente tive condições de me centrar nesse assunto e foi muito importante porque eu tive até, no doutorado, liberação do trabalho por 4 anos para me dedicar exclusivamente à tese. Isso foi decisivo. Vivia viajando para o interior, entrevistando pessoas, desloquei-me para os arquivos, ia para o Rio de Janeiro, para o Arquivo Nacional, na Biblioteca Nacional, arquivos na própria Unicamp que tem um acervo interessante, embora pequeno sobre o campesinato. Mas eu tive muita liberdade para pesquisar e para trabalhar e focar nesse assunto. Mas eu já trabalhava antes com a política de colonização no Império e, portanto, era um campesinato imigrante, mas um campesinato imigrante que ao longo da minha pesquisa eu fui ver que era um campesinato que aprendida com o outro que já existia antes aqui, com caboclos, indígenas, a população nacional que andava no campo, no meio rural. Eu acho que esse era um passo a mais que eu precisava dar e o Contestado me proporcionou dar esse passo a mais para estudar o campesinato da virada do século XIX para século XX.

7 - Durante os quase quatro anos em que a Guerra do Contestado perdurou a imprensa conseguiu analisar o conflito com profundidade ou limitou-se a reproduzir a ideologia do Estado?

Paulo Pinheiro Machado: São muito raras as análises mais críticas da imprensa sobre a ação do Estado no movimento do Contestado. Normalmente a imprensa vai não só fazer uma apologia das forças da ordem, mas também uma desqualificação dos caboclos. A imprensa daquela época era praticamente toda partidária e explicitamente partidária, mas mesmo quando os articulistas, os jornalistas, os intelectuais que escreviam nesses jornais não fossem exatamente do partido "A" ou do partido "B", mesmo assim a imprensa da época se arvorava de uma missão, Nicolau Sevcenko trabalha bem isso. Eles se achavam numa missão civilizadora, tinham como ideia a regeneração da população, a modernização da população e não conseguiam ver isso na população do interior do Brasil, isso é 
um problema não só imprensa, mas da intelectualidade brasileira em geral, que era uma intelectualidade europeizada que olha só a Europa como modelo e entende que no interior do seu próprio país só existe atraso, carências e abandono, não vê outra coisa.. Então o caboclo, o caipira, o habitante da meio rural era visto como um sujeito limitado intelectualmente, preguiçoso, indolente, doente, sem condições de ser à base de um projeto de desenvolvimento. Era esse o discurso da imprensa sobre os habitantes do Contestado, dizendo que eram pessoas facilmente enganadas por oportunistas e por lideranças que os manobravam, ou seja, não eram sujeitos do seu destino, eram pessoas facilmente iludidas por espertalhões, charlatães, era essa a construção que a imprensa fazia, além de dar pouco espaço para movimento do Contestado e quando aparecia era com aquela pecha de fanáticos. Chamá-los de fanáticos, tanto para a imprensa, como para os militares, era a chave principal do isolamento político daquela população. Quem que vai se interessar em entender o quê fanáticos dizem ou querem? São fanáticos, fanáticos são claramente pessoas insanas, irracionais, capazes de atos tresloucados e tudo o mais. E aí a própria imprensa vai se admirando da resistência desses "fanáticos", tal como faziam nas reportagens de Canudos, isso também acontece no Contestado. Além de que a imprensa na época deu muito mais espaço para notícias da Primeira Guerra Mundial na qual o Brasil só foi se envolver muito pouquinho e no final, a partir de 1917, mas assim, desde 1914 as notícias sobre a Primeira Guerra Mundial são detalhadas, longas nos jornais, há descrições super-detalhadas de deslocamentos de tropas na frente alemã, na frente franco-alemã, na frente russa, torpedeamentos ingleses, batalhas nos Bálcãs, tudo assim muito detalhado enquanto que no interior do Brasil as notícias sobre o Contestado eram pequenas notinhas de fanáticos. Então a imprensa, ela teve uma presença muito tímida sobre o movimento do Contestado. Mesmo assim aqui em Santa Catarina se formou, de 1914 para 1915, o jornal chamado Folha do Comércio, que era um jornal de dissidentes republicanos, onde um dos dissidentes da oligarquia do planalto, Henrique Rupp Júnior, um jovem advogado que fazia oposição à família Ramos que estava no poder. Ele que iria começar a levantar uma série de desmandos dos outros coronéis do planalto e da própria tropa do exército, do que acontecia no Contestado. Então há 
janelas também de denúncias, de abusos e de crimes praticados, mas são textos bastante raros na imprensa da época.

8 - Independente do período histórico brasileiro podemos observar a repressão dos diferentes movimentos populares, no entanto, o senhor acredita que a Guerra de Canudos influenciou nas políticas nacionais adotadas em relação ao Contestado?

Paulo Pinheiro Machado: De certa forma influenciou, mas não para um bom desfecho para o Contestado. Acredito que o aconteceu foi um amadurecimento da média oficialidade do exército que iria mudar sua mentalidade sobre o Brasil, sobre a política brasileira e sobre o próprio povo brasileiro. Quando houve a Guerra de Canudos os militares estavam convencidos de que aquilo se tratava de um movimento de restauração da monarquia, eles foram lá e botaram toda a energia num tudo ou nada, já que o governo republicano estava recém se consolidando no início da república, primeiros 10 anos. Os militares se sentiram fortemente ameaçados porque a república inicialmente foi praticamente um regime militar, embora Canudos já tenha acontecido no governo de Prudente de Morais, um civil. Mas o exército via Canudos como uma ameaça ao regime como um todo. Quando aconteceu o Contestado, a república já estava consolidada, mesmo os monarquistas do Rio de Janeiro já tinham aderido à república e ocupavam cargos públicos, os herdeiros da coroa já haviam renunciado ao trono, não havia possibilidade de restauração institucional da monarquia, então os militares iriam ver com muita preocupação pessoas se atirando para lutar, quase sem armas na mão, com facões e dando vivas a monarquia, para eles aquilo era muito estranho e passaram a mandar relatórios para os seus superiores, inclusive para o ministro da guerra, para políticos do Rio de Janeiro. Quem fazia isso de forma recorrente era o capitão Matos Costa, mas isso aparece também em outros escritos militares, do tenente Herculano Assumpção, do Cerqueira que era um médico militar, o próprio general Mesquita também chamava atenção para isso, que havia muito mais abusos dos potentados locais e politicagem em geral que causava a revolta da população local. Eles não usaram a palavra "coronelismo" porque essa palavra não existia naquela época no jargão político e nem nas ciências humanas. Eles chamaram de 
"mandões locais" ou "politicagem" foi isso que eles usaram, o termo "coronelismo" só iria ser usado depois dos anos 1930 de uso mais generalizado e a literatura ia contribuir bastante para isso, antes disso usavam estes termos. Então, na experiência do Contestado, embora os militares fossem disciplinados e, apesar da tentativa de mediação do capitão Matos Costa, depois de sua morte eles foram levados a repressão do movimento, mas ficou entre os militares uma pré pauta do tenentismo da década seguinte, não foi à toa que os tenentes iriam defender o voto secreto, a centralização do poder e outras formas para diminuir o poder das oligarquias regionais. Essa foi a saída que eles viam para situação do Brasil daquela época. Eles achavam, de forma um pouco ingênua talvez, porque o problema dos tenentes era ingenuidade mesmo, eles achavam que o voto secreto era a chave para acabar com o coronelismo. No entanto, veio depois o voto secreto, veio até a urna eletrônica e isso não acabou com o coronelismo. Achavam que o reforço do poder central era a chave para a diminuição do poder desses potentados locais e para a construção de uma nação, de uma modernização do país. E os militares também entendiam essa modernização com a população tal qual ela existia. Não eram como os jornalistas, como os médicos, ou como muitos políticos defensores de um branqueamento da população. A maior parte desses intelectuais do exército, muito diferente até do exército de hoje, entendia o desenvolvimento do país com a população tal qual existia naquela época.

9 - A Guerra do Contestado é um conflito ainda recente, pois conta com pouco mais de cem anos e ainda está vivo na memória dos remanescentes do conflito. Esta memória de certa forma mostrou-se uma fonte valiosa para suas pesquisas, como podemos observar no seu livro Lideranças do Contestado. Professor, quais os desafios inerentes da utilização da história oral que o senhor pode destacar com base na sua vasta experiência da questão do Contestado?

Paulo Pinheiro Machado: A memória do Contestado é uma memória dividida. Mesmo nas comunidades que foram ou que são de descendentes dos que viveram nos redutos temos uma memória dividida. Alguns reproduzem o discurso oficial dizendo "Ah, eram fanáticos, eram jagunços, Deus me livre! Meu avô, minha avó 
estavam lá porque foram levados à força!" Isso é um discurso de auto-vitimização que se sedimentou na memória dessas pessoas porque elas tiveram que viver depois da guerra e conviver com os vencedores. Então, como eles perderam a guerra ficou predominante com uma memória residual a noção de auto-vitimização, porque eles tiveram que depois se apresentar para os coronéis, baixar a cabeça e dizer que tinham ido à força para o reduto e demonizar as lideranças do Contestado, como Adeodato, Maria Rosa e outros chefes e comandantes de briga. Aí todo mundo dizia no final, ali praticamente entre dezembro de 1915 e janeiro de 1916, se apresentaram 4.000 pessoas em Canoinhas e umas 6.000 pessoas em Curitibanos, todos com o mesmo discurso: estavam à força no reduto e não podiam fugir porque o Adeodato, que era o último chefe, era um homem muito bravo. Então, com o tempo foi até se enrijecendo essa memória, exagerando essa maldade do Adeodato, o que acabava condenando todo o movimento em si. A memória do Contestado é muito complexa, por passar por diferentes fases de reelaboração, como todas as memórias que se tem, mas por ter sido uma memória de guerra e de tragédias e de muitas mortes, muitas vezes eu até entendo, por parte dos remanescentes, certa necessidade de esquecimento que faz parte assim de quem passa por uma guerra, que precisa virar aquela página e tocar a vida à diante, mesmo que tenha perdido amigos, parentes, as pessoas precisam continuar vivendo, precisam esquecer. $\mathrm{O}$ que não justifica o esquecimento dos órgãos do Estado, da educação. Mas há figuras e há, vamos dizer assim, tropos de memória que tem deslocamento de lado. Por exemplo, eu notei que tanto o professor Vinhas de Queiroz nos anos 1950-1960 como o professor Duglas Teixeira Monteiro, que foi outro grande pesquisador nos anos 1970, entrevistaram vários sobreviventes diretamente, eu só consegui entrevistar 2 ou 3 sobreviventes mesmo, que eram muito crianças na época do reduto, um deles era o João Paes de Farias, o João Ventura que quando eu falei com ele tinha 101 anos, na época da guerra ele tinha 15 anos, ele era tamboreiro dos Pares de França, que era uma guarda de elite cabocla, mas os outros que eu peguei vivos eram crianças menores, a memória deles tinha uma memória de segunda geração, do que os pais deles contavam do que propriamente deles. Nós também temos que entender esse contexto. Mas os tropos são o seguinte: há um discurso muito forte por parte por vários depoentes, 
nos anos 1950 ainda, dizendo que oficiais do exército, o Capitão Rosinha, ao pegar os prisioneiros matava até crianças, jogavam recém-nascidos para o alto e esperavam com uma espada. Essa imagem de uma espada em riste, recebendo uma criança caindo depois de ser jogada ao alto ela foi descrita como crimes praticados por militares ou por vaqueanos civis a serviço do exército, capangas do exército, que eram capangas dos coronéis e que foram colocados a serviço da tropa do exército. A memória de demonização do Adeodato foi aumentando e dos anos 1970 para 1980 essa figura da espada espetando a criança passou para o Adeodato, ou seja, então a memória oral ela é cheia dessas armadilhas, a gente não sabe nem se isso aconteceu, sabe sim que várias crianças foram mortas, que vários morreram de fome, isso nós sabemos com certeza, milhares e milhares. Agora esse acontecimento é um tipo de memória da guerra e o Portelli estuda várias dessas situações da Segunda Guerra Mundial, ele tem na memória e nas ressignificações das populações das gerações seguintes ele tem um deslocamento, muitas vezes o deslocamento é geográfico, não aconteceu lá, aconteceu em outro lugar, outras vezes o deslocamento é até social, não aconteceu por parte dos habitantes do reduto, aconteceu por parte do militares, ou vice e versa, então a memória nunca vai poder ser o material e a fonte exclusiva dos historiadores. É muito importante cruzarmos com outros documentos, mesmo que estes outros documentos sejam tão questionáveis quanto à memória. Não existe fonte isenta ou fonte segura, todas as fontes são problemáticas, então essa é uma situação assim recorrente desses estudos ligados à oralidade, a gente precisa respeitar o depoente, entender o contexto do depoimento dele, ouvir o recado que ele quer dar e depois fazer as nossas perguntas sobre isso. Mas normalmente o recado que ele quer dar, mesmo que seja "incorreto" do ponto de vista da precisão que os historiadores buscam, precisa ser entendido na sua incorreção. Por que as pessoas agregam mais alguma coisa no relato? Por que transformou este local? Por que foi necessário um discurso de auto-vitimização e de se desresponsabilizar pelo que foi feito? Nós temos que entender. A História oral estuda não só o acontecimento lá em 1912 e 1913, mas também como essas pessoas vão refletir, vão ressignificar aquele acontecimento em contextos diferentes posteriormente. Então o exercício da História oral é muito importante, porque eles nos garante 
acesso a locais onde a fonte escrita não é abundante, mas ele tem problemas e precisa sempre ser questionado e é limitado. Como todo conhecimento histórico, ele é limitado na sua capacidade de verdade, embora para nós a verdade é um processo, nunca vamos chegar a ela, um processo de aproximação de mais conhecimento e elaboração de mais conhecimento sobre essa realidade, ele é longo e precisa principalmente de uma reflexão contextual sobre os sujeitos, que são os sujeitos dessa memória e uma interação com outras fontes documentais para podermos cruzar melhor essas experiências. Há descrições de combates dos participantes do Contestado que fazem confusão entre uma guerra e outra, alguns falam em episódios que são da Guerra Federalista, participaram da Guerra Federalista, outros falam em episódios que são da guerra de 1932 contra os paulistas, eles também foram levados para lá, outros falam de outros entreveros que eram brigas locais que aconteciam entre os coronéis. A vida local daquela população do planalto era ponteada por lutas e combates, então, frequentemente na memória as pessoas acabam misturando esses conflitos também. A memória ligada à vida cotidiana podia ser até mais fiel, quando você pergunta para as pessoas: "Como era o trabalho no campo naquela época? Como é que plantavam a lavoura? Como é que cuidavam do gado?" Aí a memória tende a ser um pouco mais precisa, é mais fácil de avaliar. Então assim dependendo, os conflitos políticos e militares são muito mais suscetíveis a ressignificações, embora tudo seja suscetível a ressignificação, mas a memória tem dessas. É uma matéria muito rica, uma matéria bruta para o historiador, mas para ser transformada em História tem de ser talhada, trabalhada, contextualizada e também respeitada, porque na verdade estamos lidando com pessoas e com experiências de gerações inteiras.

10 - Durante sua passagem pela Universitat Autonoma de Barcelona o senhor teve contato com o professor Josep Fontana, um historiador conhecido pela historiografia brasileira e com vários livros publicados em português, inclusive tendo a oportunidade de entrevistá-lo. Como foi essa experiência?

Paulo Pinheiro Machado: Para mim foi uma honra porque eu já lia textos do Fontana, eu já acompanhava o seu trabalho, o 
primeiro livro que eu li dele foi sobre a quebra do Antigo Regime na Espanha e ele foi uns dos tradutores do Thompson para Espanha, acompanhou a obra do Thompson. Dentro da História espanhola ele é quase que um outsider, marginal mesmo, apesar de ser reconhecido internacionalmente, dentro da Espanha, eu me surpreendi com isso, às pessoas faziam muitas restrições ao trabalho dele, porque a historiografia espanhola quando estive lá ainda em 2010, tinha, vamos dizer assim, uma percepção muito peculiar... Como é que eu vou dizer? Os espanhóis estavam querendo se transformar em europeus, certo? É um problema dos países ibéricos, os países ibéricos tem uma espécie de complexo de inferioridade, entraram mais tarde na união europeia, viveram ditaduras cruéis até os anos 1970, então a percepção que se tinha até os anos 1970, de que a Europa terminava nos Pirineus, era marcante não só para os outros europeus, mas também para os espanhóis e portugueses. Quando eu apresentei um seminário do meu trabalho sobre o Contestado, lá na Autonoma de Barcelona para vários professores, eu apresentei que os camponeses no Contestado tinham um discurso onde eles defendiam a monarquia, e fiz um projeto de estudo comparativo para esse meu afastamento, que era um estudo da relação do movimento do Contestado e as Guerras Carlistas da Espanha do século XIX, principalmente da segunda Guerra Carlista. Por quê? As Guerras Carlistas são guerras pela sucessão do trono espanhol, começou com a disputa da linhagem da filha de Fernando VII, a infanta Maria Cristina de Bourbon, e o irmão de Fernando VII, D. Carlos. Então, o Carlos disputou o trono com a sua sobrinha, na verdade a filha do rei, depois que morreu Fernando VII e a regra da sucessão, a lei sálica não era clara de quem tinha a preferência: se era o irmão mais novo ou a filha mais velha, por ser filha, por ser mulher. $\mathrm{O}$ fato é que em torno da Maria Cristina se reuniram os liberais e constitucionalistas e em torno de D. Carlos se reuniram os setores mais ligados ao Antigo regime e ao Absolutismo, seriam os corcundas, aqueles setores mais ligados à política do Antigo Regime. E ao longo da Guerra esses setores constitucionais urbanos foram ganhando a adesão do grande clero e dos grandes terra-tenentes, dos grandes proprietários fundiários, enquanto que os carlistas foram perdendo terreno dessa antiga nobreza e ganhando apoio do campesinato pobre ao longo dessa guerra. Esse campesinato pobre assumiu o discurso do Antigo 
Regime, mas fazia isso para pagar menos impostos do que os liberais queriam e para evitar uma série de regras novas sobre o acesso à terra e até a desamortização que se fazia sobre terrenos do clero que eram habitados por muitos camponeses. Então naquele contexto o campesinato se alinhou aos carlistas, mas colocou a sua pauta própria, não uma volta ao Absolutismo, embora o discurso externo fosse esse, por isso que o Thompson é importante, para entendermos os discursos e as práticas sociais, mas na verdade o que eles faziam era prender cobradores de impostos, atacar cidades onde os liberais e a burguesia nascente aliada à antiga nobreza e até ao antigo clero, estavam transformando a modernização do país num processo de exclusão dos "de baixo". Então a "revolução", vamos dizer assim, liberal da Espanha, feita a partir do projeto da Maria Cristina de Bourbon era uma revolução "de cima para baixo", não tinha nada a ver com a Revolução Francesa, por exemplo. Então os espanhóis iam entender e chamar o movimento carlista como contra-revolução e eles me perguntaram se no Brasil o Contestado era parte da historiografia da contra-revolução, ou da contra república, eu digo: "começa que no Brasil a república não foi uma revolução", aí eles ficaram meio escandalizados quando eu disse isso, não foi uma revolução, sabemos o que significou a república no Brasil, tem toda a historiografia brasileira atual que já tem um consenso sobre isso. Eles se prenderam a situações muito formais e entendem a historiografia da revolução e a historiografia da contra-revolução como coisas separadas. Não era o que o Fontana pensava, mas era o que os historiadores jovens pensavam, isso que eu achei grave, eles estudarem a política num sentido bem antigo, formal, então eu fiquei admirado com esses jovens pesquisadores enquanto que outros... A tradição mais crítica foi a geração do Fontana e que hoje deve estar com uns 84 anos, e com outros seguidores. Tem o Santirso que é um historiador importante da Autonoma de Barcelona, que entende esse diálogo do Fontana, que entende o meu diálogo também, concorda conosco, mas essa vontade de ser europeu que está na origem desse problema, tentar fazer com que a ideia de que a Revolução Liberal na Espanha fosse semelhante à Revolução Francesa, isso para torná-los mais europeus e não entender, como a própria Rosa Congost, que é outra autora espanhola importante da atualidade, ela fez essa crítica também. Ela dizia assim "o que aconteceu na Espanha não foi uma 
Revolução Francesa, foi um processo de muito mais mudança política 'do alto' e arroxo e expropriação dos 'de baixo' do que propriamente uma transformação, tal como aconteceu em muitas regiões da França", porque a Revolução Francesa ela também não foi uniforme em várias regiões. Então essa foi uma experiência muito interessante, entrar em contato com, principalmente, historiadores agrários espanhóis, que são para mim os mais atualizados nesse debate, mas a parte ligada a uma história política eles tem isso bem separado, é diferente.

11 - Atualmente o senhor ocupa o cargo de direção do Centro de Filosofia e Ciências Humanas da Universidade Federal de Santa Catarina, quais foram os maiores desafios inerentes ao cargo?

Paulo Pinheiro Machado: Quanta coisa foi isso aqui. Primeiro que o desafio é realmente coordenar um conjunto de departamentos e de cursos numa situação bastante complicada da vida da Universidade. A Universidade cresceu. Aqui no $\mathrm{CFH}$, por exemplo, nós temos cinco cursos novos num centro em que só existiam cinco cursos, então praticamente nós duplicamos o número de cursos. Nós tínhamos como cursos antigos: Filosofia, História, Ciências Sociais, Geografia e a Psicologia. São esses os cinco cursos históricos que existem desde a antiga Faculdade de Filosofia, antes mesmo da criação da UFSC. A partir de 2008 e 2009 foram criados os cursos de Geologia, Oceanografia, Museologia, Antropologia e Licenciatura Indígena, que demandaram também uma série de especificidades, de novos laboratórios, de viagens de estudo, embarques e uma série de coisas que nos dão muito trabalho, porque as universidades públicas quando se expandem elas se expandem em algumas oportunidades, em algumas "janelas de crescimento" e nem sempre temos projetos e condições de infraestrutura ideal para fazer as coisas acontecerem. Mas é melhor que as coisas aconteçam mesmo que precariamente do que não aconteçam. Assim o nosso desafio foi esse nos últimos anos, foi de acompanhar a instalação dos novos cursos e também as demandas dos antigos que também continuam crescendo e se apresentando, vivendo num ambiente de escassez de orçamento que não foi só deste ano, vem de anos anteriores também. O duodécimo do Centro que é uma verba que nós temos de diárias, 
passagens, serviços de terceiro, material de consumo e material permanente é a mesma desde antes quando eram cinco cursos. Com os cinco cursos novos que nós recebemos não tivemos aumento da verba, é um cobertor curto que temos que lidar para dar conta das demandas e são todos cursos que tem projetos pedagógicos que exigem viagens de campo, equipamentos, laboratórios e uma série de gastos que são na verdade investimentos importantes, mas que precisamos se desdobrar para conseguir. Apesar de tudo isso, temos aumentado, o Centro tem, por exemplo, até uma linha de aquisição de livros para biblioteca, nos últimos anos tudo que foi encaminhado para o Centro para aquisição de livros para biblioteca, nós compramos, coisa que não se fazia. Durante muitos anos a Universidade ficou sem comprar livros, acho que isso é uma política importante, mas ela tem que ter continuidade, não pode parar. Aqui no CFH nós também conseguimos abrir uma editora que é a Editora do Bosque, está começando a editar as primeiras obras, já tem quatro obras editadas, sendo uma edição eletrônica disponível e aberta totalmente livre ao público porque para nós os autores não querem vender livros, eles querem simplesmente ser lidos, então muitos tem submetidos essas obras ao nosso Conselho Editorial aqui do NUPPE de publicações. O que nós queremos é aumentar essa estrutura do NUPPE, porque hoje só tem uma funcionária e duas bolsistas, aumentar essa estrutura para que as linhas dessas publicações que se chama Coleções do Bosque possam se ampliar e principalmente para jovens autores, porque são os jovens autores que têm mais dificuldade de publicar em editoras universitárias ou até editoras comerciais. Então a edição do CFH surge para atender a esse público, que tem uma produção nova, inovações, tem trabalhos, teses e dissertações também e que lançariam isso para um público amplo que é o público da internet, para o mundo inteiro, isso é uma área de reforço importante da nossa atuação, além do atendimento das demandas dos departamentos que é constante. A nossa estrutura aqui é pequena, mas com um pessoal bem preparado na secretaria, conseguimos na maioria das vezes atender a essas demandas, mas sempre temos muita precariedade na área de equipamento e infraestrutura que não depende do Centro, depende da Prefeitura Universitária que tem que atender não só o campus de Florianópolis mas também o do interior. Esse é um dos pontos de estrangulamento, não só da nossa, mas de outras 
Universidades Federais, eu estive acompanhando, em contato com outros diretores de unidade o que eles vivem. Para mim essa tem sido uma experiência completamente nova de administração e eu acho importante que todos os professores em algum momento da sua carreira passem por ela, porque a Universidade é gerida pelos seus pares, é gerida por órgãos colegiados e pelos professores e professoras, então é uma experiência que mistura o projeto acadêmico com um pouco de gestão de edifícios, espírito de síndico de condomínio, que é a parte pesada e ruim do processo, [risos] porque de vez em quando estoura um cano, quebra um telhado, coisas assim acontecem e que nos tiram daquilo que seria um projeto interessante de fazer, um projeto de extensão, chamar os departamentos para participar, atender a demanda de uma comunidade. Mas hoje o nosso Centro tem dez cursos de graduação, oito programas de pósgraduação, tem uma extensão muito forte em comunidades urbanas, favelas e comunidades pobres, no meio rural também, projetos que vêm dos departamentos ligados a comunidades pesqueiras, comunidades indígenas, comunidades quilombolas, agricultores da reforma agrária, regiões coloniais. Então o CFH trabalha e a UFSC como um todo, mas falando aqui do $\mathrm{CFH}$ que eu conheço, trabalha muito além das salas de aulas e laboratórios que estão aqui colocados, temos uma equipe muito boa e um Centro onde até os conceitos dos programas de pósgraduação vêm melhorando, melhorando apesar das dificuldades e dos problemas materiais. É que o nosso melhor capital é o capital humano e eu acho que numa Universidade sempre vai ter que ser o melhor capital.

12 - Para encerrar gostaria de trazer a nossa conversa ainda mais para o tempo presente. A construção da história bem como a construção da memória se dá, na maioria das vezes, de forma inconsciente e através do dia a dia. Agora eu gostaria de instigar o senhor a fazer o processo contrário e adotar essa consciência. Partindo do pressuposto de que esta entrevista constituirá uma fonte histórica para a posterioridade, ou seja, uma janela aberta para o Brasil de 2015 com todas as suas especificidades, que considerações o senhor gostaria de fazer sobre a turbulência política e econômica que o nosso país está atravessando, e sobre o fato de o tema 
"impeachment" está presente diariamente nos jornais, com o intuito de ajudar as futuras gerações na compreensão do momento atual?

Paulo Pinheiro Machado: O que acho é que existe hoje no país uma radicalização política liderada por setores, eu não digo nem ultraconservadores porque conservadorismo é deixar as coisas como estão, são setores reacionários, setores que não admitem mudança social, pois mudança social mesmo que tímida no Brasil provoca reações das classes conservadoras. Para mim isso é muito claro: houve um projeto que foi derrotado nas eleições e que agora tenta virar a mesa, promover um golpe no país. O mais grave de tudo é que existe o crescimento de um discurso de vertente fascista que busca transformar a política num campo só de forças, agressões e de pedradas e não num campo da argumentação, da disputa de projetos e na construção de algo melhor a partir da argumentação, da educação política, da elevação do nível do debate político. Então há uma política rasa de uso da corrupção, a corrupção existe mesmo, não estou dizendo que não existe. $\mathrm{O}$ uso da corrupção como uma cortina de fumaça para que não se discutam os principais problemas do país. O maior problema do Brasil não é a corrupção, o maior problema do Brasil é a desigualdade social. Apesar de todos os problemas deste governo, e eu não sou propriamente um entusiasta dele, não sou embora até tenha votado, apesar de todos os problemas deste governo houve um crescimento da renda dos pobres no Brasil nos últimos 15 anos, isso é muito claro, o aumento do salário mínimo proporcionou isso. Isso despertou expectativas nessa população que teve uma melhoria de vida por conta do Bolsa Família e de várias outras políticas sociais. E na Universidade nós vemos esse mesmo conflito que existe na sociedade, aqui na Universidade há gente que é contra a política de cotas, tem gente que é contra as cotas para alunos que vem da escola pública, tem gente que é contra cotas para negros e indígenas, dizendo que "não, a universidade tem que ser só do mérito e da excelência" o que é uma falsidade, que o mérito e a excelência é a universidade antiga que é só dos brancos e ricos, é isso que eles querem. E, no entanto, se nós formos ver, os alunos cotistas têm melhores condições de aproveitamento escolar do que os não cotistas, em todas as universidades brasileiras esse é um dado que vem sendo apurado, o índice de conclusão dos cursos é muito maior entre os 
cotistas do que os não cotistas. Então é uma falsidade atribuir aos cotistas à falta de condições de concluir o curso. É claro que a Universidade precisa se preparar para essa inclusão social e para essa diversidade, diversidade étnica, diversidade social, diversidade até de gênero, esse é um desafio. E, no entanto, a luta política no Brasil hoje é entre a democracia e o fascismo, mesmo que com outras formas, por isso que eu vejo como algo muito grave o momento que nós vivemos hoje e é um desafio até para os historiadores, chega a ser escandaloso vermos nas ruas pessoas com faixas pedindo intervenção militar, e não é que seja pedir intervenção militar, é saber que a intervenção militar é um pacote completo que implica na ilegalidade, na violência, na tortura, na delação e todas as práticas horríveis que eu vi, eu vivi isso, eu sei o que significa para quem luta pela justiça e pela democracia um retrocesso desse nível. Então realmente o país vive uma situação muito grave e como dizia o Walter Benjamin: "Se nós perdermos, a nossa memória também será perdida, se nós perdermos, até os nossos mortos estarão em perigo". Aqueles que lutaram contra a ditadura, que tentaram construir a democracia para a sociedade brasileira, que foi um processo até inconcluso, a democratização da sociedade brasileira ainda é um processo inconcluso, porque enquanto houver grandes níveis de desigualdade social a nós vamos continuar numa sociedade não democrática, então eu acho que o que está em debate hoje no Brasil é: ou nós continuamos num regime democrático, minimamente democrático, dentro de uma ordem estabelecida ou nós vivemos um retrocesso muito grande e uma perda das conquistas sociais em todos os campos, inclusive no campo universitário. É isso.

RECEBIDA EM: 26/02/2016 APROVADA EM: 13/06/2016 